\title{
A Review on Effect of Temperature Change on Mechanical Parameters of Fine Soils
}

\author{
Hamed Hoseinimighani ${ }^{1 *}$, Janos Szendefy ${ }^{1}$ \\ ${ }^{1}$ Department of Engineering Geology and Geotechnics, Faculty of Civil Engineering, Budapest University of Technology and Economics, \\ Múegyetem rkp. 3, H-1111 Budapest, Hungary \\ * Corresponding author, e-mail: hoseinimighani.hamed@emk.bme.hu
}

Received: 28 May 2020, Accepted: 25 February 2021, Published online: 24 March 2021

\begin{abstract}
Temperature change in soils and its possible effects date back to 20th century where temperature difference between laboratory and field for sampling made researchers interested in this topic. Due to development of technology and industry nowadays, new engineering applications such as nuclear waste disposal, oil extraction and pipelines, geothermal structures etc. have turned temperature change in soils to one of the high trending research topics where suitable knowledge of thermal effects on soils is required. For this purpose, it is tried at first to highlight the importance of temperature effect on geotechnical design by some examples and possible effect of temperature change on mechanical properties of fine soils are reviewed afterward. Investigation on results from literature proved that temperature change could alter some strength and consolidation parameters of fine soils. Different factors are proposed to be responsible for such thermally induced changes in mechanical parameters, however, existing explanations and comments from literature are diverse and not fully understood yet. In order to fill this gap, it is tried to find connections between different mechanical parameters and their behavior toward temperature change and possibly find a unified approach and factor to explain the mechanism responsible for thermally induced changes in mechanical parameters of fine soils. Finally, at the end, it is concluded that effect of temperature on structural rearrangement of solid particles could be a promising factor to connect the responses of different mechanical parameters toward temperature change.
\end{abstract}

Keywords

temperature, thermal effects, consolidation, geothermal, soil

\section{Introduction}

Temperature change and its potential effect on soil properties and behavior have become an important part of many engineering designs and applications. It started at mid20th century when Gary [1] did the first odometer test at different temperature of 10 and $20^{\circ} \mathrm{C}$ in 1936. Paaswell [2] conducted heating test at constant load using odometer ring in 1967 and the first conference with focus on temperature related issues in soils was held in Washington DC USA in 1969. Studies of other researchers can be found in literature [3, 4, 5-15].

The range of studied temperature in early research was limited (usually between 10 to $50^{\circ} \mathrm{C}$ ). The reason of such limitation was related to researcher's interest, which was the temperature difference between laboratory and field where samples were being taken. Nowadays, however, development of technology and industry have caused new and more complicated engineering applications to arise, such as nuclear waste disposal, oil extraction and pipelines, geothermal structures, encouraging researchers to have a better understanding about the temperature effect in soil up to $100^{\circ} \mathrm{C}$ and even more when dealing with thermal treatment of contaminated soils.

Ability of clayey soils like seepage control, pollution prevention, heat insulation and radiation protection could make it an ideal environment for nuclear waste disposal. On the other hand, it can cause the soil to face temperature change up to $100^{\circ} \mathrm{C}$ because of chemical reactions of wastes. Thus, the importance of soil behavior toward temperature change made many researchers to work in this field to have better and safe design for long-term function of these disposal areas.

Recent studies on High Level nuclear Waste (HLW) disposal program in France and Switzerland could be illustrating examples. For having a better understanding of behavior 
of the host medium (mainly clayey soils and clay stones) toward thermal load induced from the waste especially in long-term during thousands of years, many small-scaled and field-scaled experiments as well as numerical modeling and simulations have been done by researchers [16-19]. Akinwunmi et al. [20] studied the behavior of bentonite toward temperature change since generally bentonite is used as barrier for HLW disposals. For instance, in [20], disposal area is located in Finland $400 \mathrm{~m}$ below the ground.

Another engineering application involving temperature change is waste management and design of landfills and Geosynthetic ClayLiner(GCL).Chemicalreactionsofwastes and temperature fluctuation of environment can cause surrounding area including GCL to face elevated temperature which might lead to alternation of mechanical and hydraulical properties of bentonite inside the GCL and even the whole barrier system [21-23]. For instance, temperature rise up to $50^{\circ} \mathrm{C}$ in copper leach pads [24], $70^{\circ} \mathrm{C}$ in nickel leach pads [25], $60^{\circ} \mathrm{C}$ in municipal wastes [26] and even more than $100^{\circ} \mathrm{C}$ in aluminum waste [27] have been reported [21].

Among different types of geothermal structures, GroundSource Heat Pump (GSHP) is the most common type for space heating and cooling [28-34]. GSHPs are connected to a network of buried tubes, called Ground Heat Exchanger (GHE), through which water is being circulated $[28,31]$ and are commonly divided into two types namely openloop and close-loop systems and direct contact between circulating fluid and surrounding medium is the difference between them. Regarding close-loop systems, a network of tubes is buried under ground either vertically or horizontally [28]. Nevertheless, due to high excavation costs especially for vertical GHEs, another type of heat exchanger has become popular called energy pile. A network of tubes is placed inside the pile foundation to make both mechanical and geothermal structure [28, 29, 31, 35]. Heat pump function and circulation of fluid through the pile foundation will cause temperature fluctuation in pilesoil interface, pile, and surrounding soil. First experiment regarding this issue was done by Morino and Oka [36]. During past years, temperature change and its effect on shear behavior of pile-soil interface, side and end bearing capacity of the pile, axial and radial deformation etc. have been gaining higher attention among researchers and many studies have been done [29, 31, 35, 37-41].

The importance of temperature and its possible effects on physical and mechanical properties of soil have been highlighted by some examples of engineering applications.
The aim of this paper is to make a detailed review and summarization about soil mechanical properties as well as their possible alternation due to change in temperature. This information is of high importance and can help us to understand opportunities and challenges associated with these kinds of geotechnical design and to make sure about the quality and safety for design of structures dealing with temperature change.

\section{Effect of temperature on mechanical parameters 2.1 Consolidation parameters}

Construction of structures causing temperature change in soil should be assessed carefully to not face any undesirable outcome for soil settlement. In this case, it is essential to have sufficient knowledge about the effect of temperature change on settlement and consolidation parameters.

\subsubsection{Permeability (hydraulic conductivity)}

Change in permeability of soil due to change in temperature can be related to effect of temperature on viscosity of water. Hillel [42] proposed the equation below to predict the effect of temperature on viscosity of water:

$\mu_{T}=-0.00046575 \ln \left(T / 1^{\circ} \mathrm{C}\right.$ or $\left.K\right)+0.00239138$.

$T$ is temperature and $\mu_{T}$ is viscosity of water at temperature $T$. This relationship shows that viscosity of water will decrease with increase in temperature. Therefore, the ratio between permeability at tested temperature $k(T)$ and permeability at ambient temperature $k\left(T_{0}\right)$ could be calculated as Eq. (2) [43]:

$\frac{k(T)}{k\left(T_{0}\right)}=\frac{\mu\left(T_{0}\right) \gamma_{w}(T)}{\mu(T) \gamma_{w}\left(T_{0}\right)}$.

$\mu\left(T_{0}\right)$ is viscosity of water at ambient temperature, $\gamma_{w}\left(T_{0}\right)$ and $\gamma_{w}(T)$ are density of water at ambient temperature and at temperature $T$, respectively.

Results of consolidation tests could be used to calculate permeability of soil as an indirect method (e.g. [4] and [5]). Abuel-Naga et al. [44] reported increase in permeability by increase in temperature as well as a good agreement between experimental and calculated results (Eqs. (1)-(2)).

Direct measurements of permeability at different temperature have also been investigated by researchers (such as [45]). Delage et al. [46] conducted direct measurement of permeability at various temperature for Boom clay using constant head method. Their results also showed increase in permeability under constant effective stress due to heating and decrease in permeability during 
cooling phases. The change in permeability by temperature change was attributed by [46] to change in viscosity of water. For this case, intrinsic permeability was also studied in this research and Fig. 1 shows that intrinsic permeability is independent of temperature and relies only on porosity (or void ratio).

Abuel-Naga et al. [43] conducted direct measurement of permeability on undisturbed samples of soft Bangkok clay under various thermal and mechanical loading conditions using constant head flexible wall method.

Their results in Fig. 2 show that with increase in temperature, permeability is increasing. They attributed these results to effect of temperature on physical properties of water such as viscosity. In order to make sure of this assumption, authors also studied intrinsic permeability and its change by temperature and similar to [46], independency of intrinsic permeability toward temperature change was concluded. Based on the observation on intrinsic permeability, it is commented in [43] that attributing the temperature effect on permeability to temperature effect on physical changes of water is correct and in constant void ratio, any change in permeability by temperature could be calculated using Eq. (2).

Chen et al. [47] studied the effect of temperature on permeability of Boon clay samples similar to [46] using direct measurement method with modified triaxial cell and reported increase in both vertical and horizontal permeability during heating as well as reversible feature upon cooling. They also compared measured values of permeability at different temperature with predicted results using the effect of temperature on viscosity and density of water (Eq. (2)). Despite of good agreement between measured and predicted results, they noticed that measured values are somewhat lower than predicted ones. Based on these results, it was commented in [47] that other factors could attribute to change in permeability due to change in temperature alongside change in viscosity of water such as microstructural change in clay fabric. Fig. 3 shows intrinsic permeability and its evolution with temperature for this study. Intrinsic permeability relies only on void ratio while Fig. 3 shows reduction in intrinsic permeability upon heating and small increase during cooling. These results prove that other factors such as structural change in soil due to change in temperature should be considered to predict permeability of soils at different temperature. A new prediction model considering change in physical properties of water and microstructural changes in soil was proposed by [47]:
$k(T)=k\left(T_{0}\right) \frac{\rho_{w}\left(T_{0}\right) \mu_{w}\left(T_{0}\right)\left(\varepsilon_{v}+n_{0}\right)^{3}}{\rho_{w}(T) \mu_{w}(T) n_{0}^{3}\left(1+\varepsilon_{v}\right)}$

$\varepsilon_{v}$ is volumetric strain, $n_{0}$ is initial porosity, $\rho_{w}\left(T_{0}\right)$ and $\rho_{w}(T)$ are density of water at initial temperature and temperature $T$, respectively.

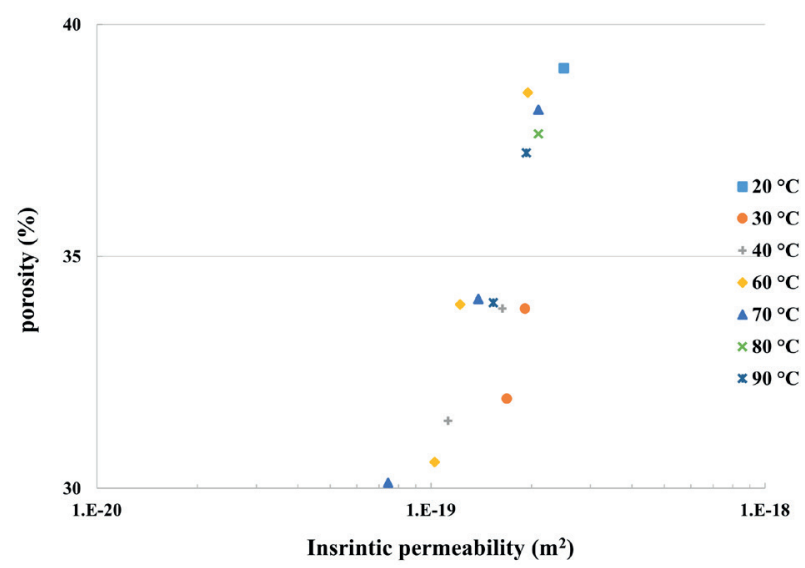

Fig. 1 Variation of intrinsic permeability of Boon clay by temperature (redrawn after [46])

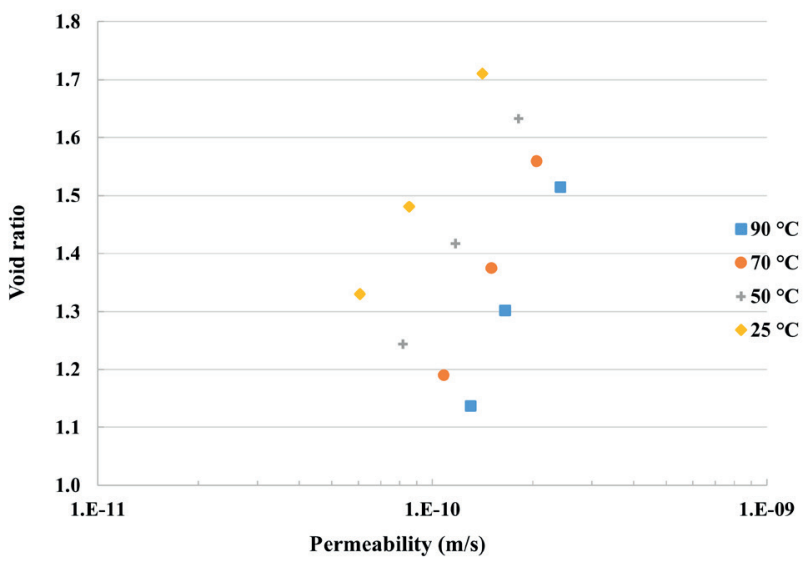

Fig. 2 Effect of temperature on permeability of soft Bangkok clay (redrawn after [43])

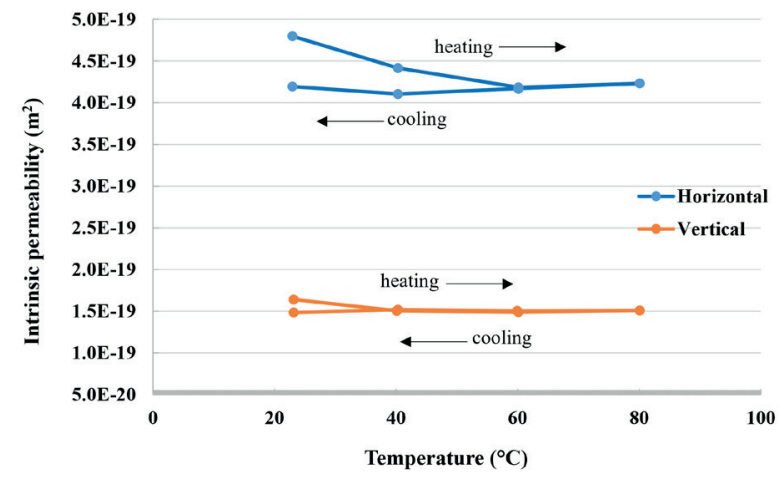

Fig. 3 Variation of intrinsic permeability of Boon clay by temperature (redrawn after [47]) 


\subsubsection{Preconsolidation pressure}

Another consolidation parameter in fine-grained soil is preconsolidation pressure that corresponds to maximum past pressure experienced by the soil. Accordingly, soil is in over consolidated state if it is loaded below the preconsolidation pressure and it is in normal consolidated state if it is loaded higher than preconsolidation pressure. With this concept, the ratio of over consolidation is defined as:

$\mathrm{OCR}=\frac{P_{c}}{P_{0}}$

OCR is over consolidation ratio, $P_{c}$ is preconsolidation pressure and $P_{0}$ is in-situ (current) pressure. Volume change behavior of soil is different in over consolidated and normal consolidated state hence it is important to have knowledge about the effect of temperature on preconsolidation pressure.

Sultan et al. [48] studied the effect of temperature on preconsolidation pressure of four Boom clay samples using modified triaxial cell and reported that preconsolidation pressure is decreasing with increase in temperature. Sultan et al. [48] also compared these experimental results with two numerical formulations proposed in [49] and [50]. Hueckel and Baldi [49] proposed Eq. (5) for preconsolidation evolution with temperature changes by extending hardening law of cam-clay model, as follow:

$$
\begin{aligned}
P_{c}^{\prime} & =P_{c 0}^{\prime} \exp \left(\frac{1}{\lambda-\kappa_{T}}\left[e_{1}-e_{g}+\left(1+e_{0}\right) \varepsilon_{V}^{P}\right]\right) \\
& +2\left(a_{1} \Delta T+a_{2}|\Delta T| \Delta T\right) .
\end{aligned}
$$

$P_{c}^{\prime}$ is the preconsolidation pressure (yield stress) at temperature $T, P_{c 0}^{\prime}$ is the preconsolidation pressure at initial temperature $T_{0}, \varepsilon_{v}{ }^{P}$ is plastic volumetric strain, $\Delta T$ is change in temperature, $\lambda$ is the Cam-clay compression coefficient, $\kappa_{T}$ is the elastic coefficient at temperature $T$, $e_{0}$ is the initial void ratio, $e_{1}$ is a hypothetical void ratio defined by $P_{c 0}$ and initial temperature $T_{0}, e_{g}$ is the void ratio corresponding to $P_{c}, a_{1}$ and $a_{2}$ are two parameters expressing the decrease of the preconsolidation pressure $\left(P_{c}\right)$ with temperature increase.

Baldi et al. [51] proposed values of $-4.302 \times 10^{-2} \mathrm{MPa}^{-1}$ and $1.101 \times 10^{-4} \mathrm{MPa} . \mathrm{C}^{-2}$ for $a_{1}$ and $a_{2}$ respectively, for Boom clay. Picard [50] modified the model proposed in [49] afterward as:

$$
P_{c}^{\prime}=P_{c 0}^{\prime} \exp \left(-3 \frac{1+e_{0}}{\lambda-\kappa} \alpha_{p} \Delta T\right) .
$$

$\alpha_{p}$ is a positive scalar coefficient, with the unit of $1 / \mathrm{C}$. This was given by [50] as $1 \times 10^{-4} \mathrm{C}^{-1}$ for Boom clay. A very good agreement between experimental results and prediction model by Picard [50] was observed in the study of [48].

Cekerevac and Laloui [52] reported decrease in preconsolidation pressure for clay classified as CM by Unified Soil Classification System (USCS) and a prediction model was proposed by authors as a function of volumetric plastic strain and temperature as follow:

$$
\sigma_{c}^{\prime}(T)=\sigma_{c}^{\prime}\left(T_{0}\right)\left(1-\gamma\left[\frac{T}{T_{0}}\right]\right) .
$$

$\sigma_{c}^{\prime}\left(T_{0}\right)$ is the preconsolidation pressure at a reference temperature $T_{0}, \sigma_{c}^{\prime}(T)$ is the preconsolidation stress at a given temperature $T . \gamma$ is a material parameter to be obtained by fitting Eq. (7) to experimental results and it can be related to liquid limit (LL) according to [53]. Laloui and Cekerevac [54] suggested values for $\gamma$ as 0.18, 0.10, 0.246 and 0.075 for Boom clay, MC clay, Illite and Kaolin clay, respectively.

Abuel-Naga et al [44] studied temperature dependency of preconsolidation pressure of soft Bangkok clay. Results of their study showed $24 \%$ and $22 \%$ reduction in preconsolidation pressure at $90{ }^{\circ} \mathrm{C}$ for samples under 100 and $200 \mathrm{kPa}$ consolidation pressures, respectively, concluding that stress level does not have significant effect on preconsolidation evolution by temperature change.

Authors compared the results with Eq. (7) and another equation proposed in [55] as below:

$\sigma_{c}^{\prime}(T)=\sigma_{c}^{\prime}\left(T_{0}\right)\left[\frac{T}{T_{0}}\right]^{\alpha}$.

$\alpha$ is parameter related to soil type. Abuel-Naga et al. [44] adopted $\alpha=0.16$ and $\gamma=0.42$ for soft Bangkok clay.

Tsutsumi and Tanaka [56] studied the effect of temperature on three types of clay samples named OsakaMa12 collected from construction site of the Kansai International Airport in the Osaka Bay in Japan, Louiseville clay from Canada and commercial powder clay named as Kasaoka and reported decrease in preconsolidation pressure. They also compared experimental results with Eq. (7) proposed by Cekerevac and Laloui [52] and a good agreement is observed between the model and experimental results specially for OsakaMa12 samples. Tsutsumi and Tanaka [56] believed that the assumption of Cekerevac et al. [53] for dependency of parameter $\gamma$ on liquid limit is true since they observed that samples with higher liquid 
limits (62, 71 and $109 \%$ for Kasaoka, Louiseville and OsakaMa12 samples) had higher values forparameter $\gamma$.

Fig. 4 shows the evolution of preconsolidation by temperature change based on results from literature. It can be seen that soils with higher liquid limit showed higher reduction in preconsolidation pressure and accordingly showed higher value for parameter $\gamma$ which proves the assumption by $[44,53]$. Fig. 5 also shows the values adopted for parameter $\gamma$ for different samples from literature and increase in $\gamma$ by increase in liquid limit is observed.

Jarad et al. [57] also reported decrease in preconsolidation pressure for a clay sample with high plasticity where the effect of temperature on preconsolidation pressure of another clay with low plasticity is not significant.

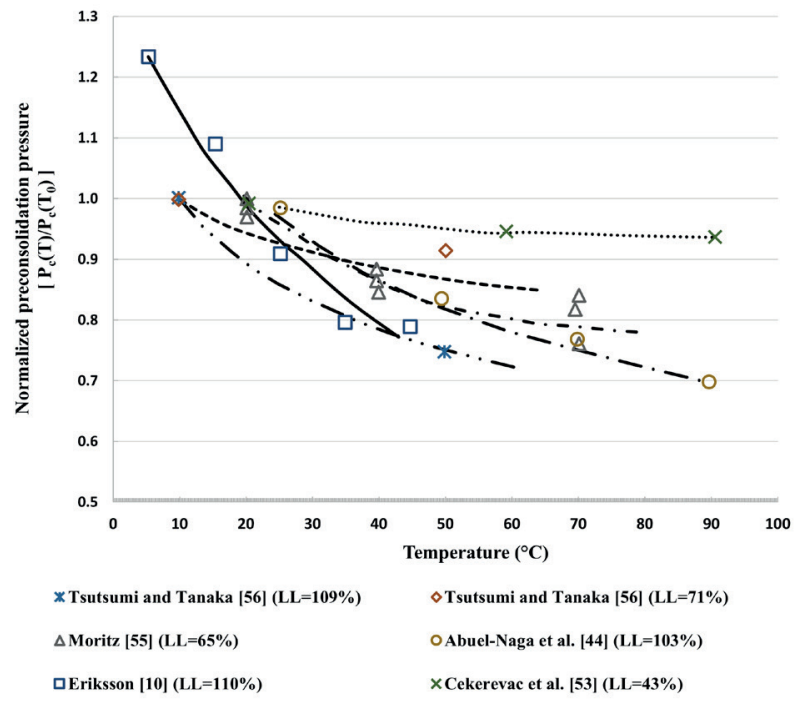

Fig. 4 Effect of temperature on preconsolidation pressure [after 44]

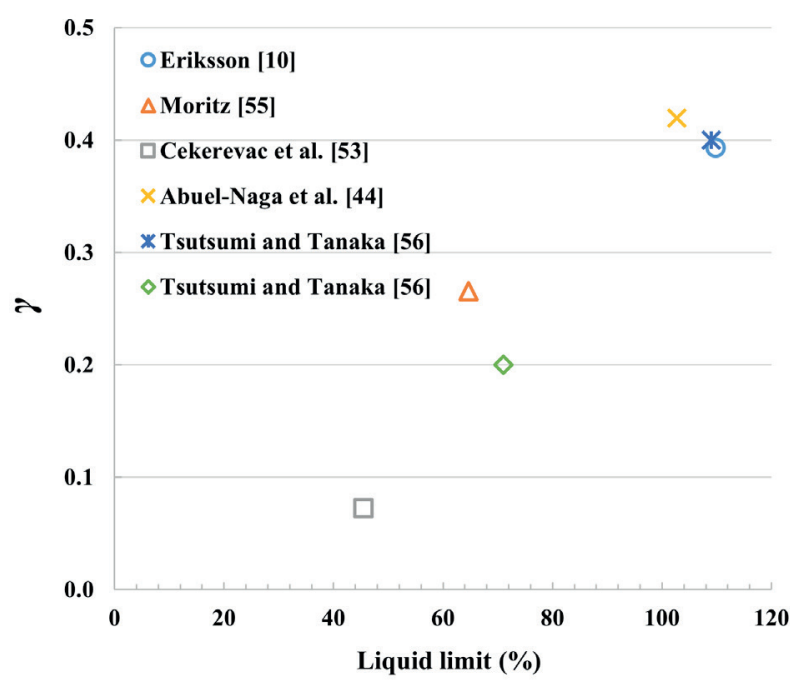

Fig. 5 Relationship between parameter $\gamma$ and liquid limit (after [53])
These behavior of two types of clay here are following the assumption of Cekerevac et al. [53] for the effect of liquid limit on the level of temperature influence on preconsolidation pressure.

It worth to mention that Xiong et al. [58] developed a formulation for effect of temperature on preconsolidation pressure very recently based on the assumption of Cekerevac and Laloui [52] as:

$P_{c}(T)=P_{c}\left(T_{0}\right)\left[\frac{3 \alpha_{T} \Delta \theta\left(1+e_{0}\right)}{\kappa}\right]$.

Where $e_{0}$ is initial void ratio and $\kappa$ is the swelling index within cam-clay model for soils. Increase in value of linear expansion coefficient or decrease in value of swelling index will cause greater decrease in preconsolidation pressure which acts similar to parameter $\gamma$ proposed by Cekerevac and Laloui [52]. A very good agreement between experimental results and Eq. (9) is reported by Uchaipichat [59].

Kaddouri et al. [60] also reported decrease in preconsolidation pressure in their experiments on CL samples. Authors also tried to calibrate the first model propped by Hueckel and Borsetto [61] considering the effect of temperature on preconsolidation pressure as follow:

$P_{c}(T)=P_{c}\left(T_{0}\right)+\alpha_{1} \Delta \theta+\alpha_{2} \Delta \theta|\Delta \theta|$.

$\alpha_{1}$ and $\alpha_{2}$ are the same as described for Eq. (5) and it was proposed as -0.0909 and -0.0008 respectively, for CL clay from eastern France by Kaddouri et al. [60].

\subsubsection{Coefficient of consolidation $\left(C_{v}\right)$ and volume compressibility $\left(m_{v}\right)$}

Coefficient of consolidation defines the rate of settlement and it is based on consolidation theory of Terzaghi [44], it can be calculated as follow:

$C_{v}=\frac{k}{\gamma_{w} m_{v}}$.

$k$ is permeability and $m_{v}$ is coefficient of volume compressibility. Delage et al.'s work [46], as an early study, on Boom clay could be a good example where they concluded that the effect of temperature on $C_{v}$ is negligible. They reported a slight increase in $C_{v}$ during initial heating and after that, $C_{v}$ is almost constant for higher temperature. Authors attributed this small change in $C_{v}$ to two simultaneous and opposite factors. Increase in permeability, which is counterpartyed by decrease in void ratio due to change in temperature. Small decrease in $m_{v}$ by increase in temperature is also reported in [46]. 
Bag and Rabani [62] studied the effect of temperature increase on consolidation and swelling pressure for commercial bentonite and local soil from India which are classified as $\mathrm{CH}$ and $\mathrm{CL}$, respectively, using modified oedometer device. It was observed that for bentonite, $m_{v}$ is decreasing with increase in pressure and the effect of temperature is negligible. Whereas, for local Indian clay it was reported that $m_{v}$ is increasing slightly with increase in temperature for pressure lower than $400 \mathrm{kPa}$. This effect of temperature on $m_{v}$ is becoming smaller by increase in pressure. Similar to result for bentonite, increase in pressure caused decrease in $m_{v}$ and after pressure of $400 \mathrm{kPa}$; the effect of temperature on $m_{v}$ is negligible.

Jarad et al. [57] studied effect of temperature on consolidation of clayey soils using modified oedometer device. Two types of clay were studied from eastern Germany and eastern France classified as $\mathrm{CH}$ and $\mathrm{CL}$, respectively in accordance with USCS. For both clays, it is observed that coefficient of consolidation is increasing with increasing the temperature. These results are different from the work in [46] and it was attributed to effect of temperature on permeability. Result from this study matches very well with the work in [62] for local Indian clay.

Both studies showed increase in $m_{v}$ with increase in temperature for pressure lower than $400 \mathrm{kPa}$ and effect of temperature on $m_{v}$ is negligible for pressure higher than $400 \mathrm{kPa}$.

Takai et al. [63] studied the effect of temperature on consolidation of clay with modified oedometer device. Two types of Kaolin and Kasoka clay were used in this study both classified as CH by USCS and an increase in consolidation coefficient with temperature increase was reported by authors. They assumed that $C_{v}$ is increasing by temperature logarithmically and Fig. 6 shows a strong relationship between increasing rate of $C_{v}$ and liquid limit for different type of samples from literature [63, 64]. Authors believed that thickness of diffused double layer will decrease with increase in temperature and therefore the effect of temperature on $C_{v}$ will be more significant for soils having higher liquid limit, which will be further investigated in following sections.

After reviewing the results, increase in $C_{v}$ and $m_{v}$ by increase in temperature can be seen. Effect of temperature on permeability can be one reason for increase in $C_{v}$. As it was discussed, permeability is increasing by increase in temperature which will lead to faster dissipation of pore pressure and faster rate of consolidation. Moreover, these findings can also be related to effect of temperature on viscosity of water and viscous shear resistance between particles and tendency of particles to rearrange more easily.

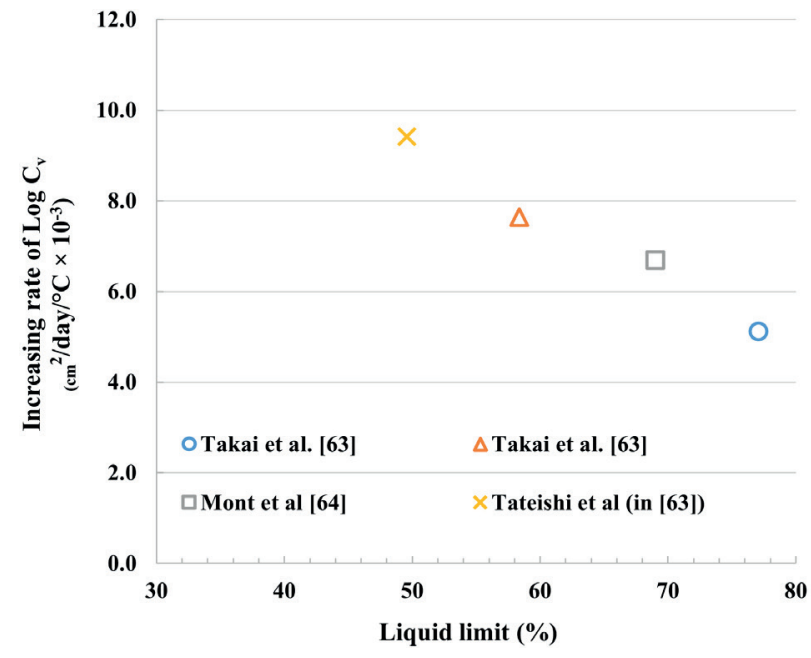

Fig. 6 Relationship between increasing rate of $C_{v}$ and liquid limit (redrawn after [63])

\subsubsection{Compression index $\left(C_{c}\right)$ and swelling index $\left(C_{s}\right)$}

In consolidation process, the slope of $e-\log \sigma^{\prime}$ curve in normal consolidated and over consolidated state are commonly known as compression $\left(C_{c}\right)$ and swelling $\left(C_{s}\right)$ index, respectively, which define the volumetric behavior of fine soils. Cekerevac and Laloui [52] studied the effect of temperature on compression index of CM clay using modified triaxial cell. They found out average $C_{c}$ at 22 and $90^{\circ} \mathrm{C}$ are 0.24 and 0.23 respectively concluding that temperature has no effect on $C_{c}$. Di Donna and Laloui [65] studied the effect of thermal cycles on two types of silty clay samples both classified as inorganic clay with medium plasticity according to USCS and it is observed that temperature has insignificant effect on compression and swelling indexes.

Jarad et al. [57] also studied the compression and swelling indexes under different temperature. They, however, commented that $C_{c}$ is increasing with increase in temperature and $C_{s}$ values do not depend on temperature.

Bag and Rabbani [62] also investigated the effect of temperature on $C_{c}$ and $C_{s}$ in their study and temperature seemed to have no significant effect on compression index of local Indian clay. However, compression index of bentonite is increasing with increase in temperature. Kaddouri et al. [60] reported that temperature variation slightly changed the compression and swelling index for ilitic clay classified as CL based on USCS from eastern France.

By reviewing the results, it can be seen that temperature generally does not have significant effect on $C_{s}$ (swelling index). On the other hand, increase in $C_{c}$ by increase in temperature is seen from some of the results specially for soil with higher plasticity such as bentonite. These results can also be related to effect of temperature on viscosity of water and decrease in viscous shear resistance between 
particles accordingly. As it was seen in Sections 2.1.2 and 2.1.3, sensitivity of preconsolidation pressure and $C_{v}$ could be related to $L L$ (liquid limit). It can be concluded from the results in this section that same approach can be adopted for sensitivity of $C_{c}$ toward temperature change since soil with higher plasticity (higher liquid limit) showed an increase in $C_{c}$ by increase in temperature whereas soils with low plasticity showed rather no dependency of $C_{c}$ on temperature.

\subsubsection{Creep index $\left(C_{a}\right)$}

Consolidation process in fine-grained soil is divided into two parts. First part, called primary consolidation, is where excess pore water pressure, caused by increase in load, is dissipating through time and void ratio of soil starts to decrease. After the end of primary consolidation and dissipation of all excess pore water pressure, soils continue to settle with much lower rate due to rearrangement of soil skeleton since all excess pore water pressure are dissipated and the load are being transferred to solid particles. This part of consolidation is called creep or secondary consolidation, which starts, theoretically, right after the end of primary consolidation. The rate of volume change in this part is commonly known as creep index, creep coefficient or secondary compression index.

Zhang et al. [17] studied the effect of temperature on creep index for COX claystone as host for high nuclear waste disposal in underground research laboratory at Bure, France. It was observed that upon heating up to $90^{\circ} \mathrm{C}$, creep rate is increasing. Authors attributed this increase in creep rate to reduction of viscosity of water by increase in temperature as well as reduction in resistance of bound water films between solid particles. These two effects can help solid particles to rearrange more easily and faster.

Jarad et al. [57] used the method proposed by Mesri and Godlewski [66] which relates the creep index to compression index. Based on this method, authors believed that the value of $C_{\alpha} / C_{c}$ at a given temperature is equal to the slope of preconsolidation pressure-strain rate logarithmic curve $\left(\log \dot{\varepsilon}-\log p_{c}\right)$, i.e., $C_{a} / C_{c}(T)=\Delta \log p_{c} / \Delta \log \dot{\varepsilon}(T)$. With their result of temperature effect on compression index, discussed previously, they could measure the creep index at different temperature. Despite of a decrease in creep index at $47.6^{\circ} \mathrm{C}$, the overall creep index increased considerably with increase in temperature for clay sample with high plasticity. In addition, a slight increase in creep index was observed for the other clay sample with low plasticity. The different behavior of two clay samples toward temperature in terms of creep index was attributed to different mineralogy by authors and they also attributed the acceleration in creep to effect of temperature on viscosity of free water and bound water and resistance of solid particles.

Li et al. [67] studied the effect of temperature on Utby clay from Gothenburg, Sweden using oedometer device and both intact and remolded samples were used in this study. The tested soil was ilitic clay with high sensitivity and samples were collected from depth of 6 and $9 \mathrm{~m}$ below ground and the range of studied temperature was $5-25^{\circ} \mathrm{C}$. It was reported that variation of creep index highly depends on structure of the soil where intact samples showed considerable effect of temperature and vertical effective stress on creep index especially around apparent preconsolidation pressure. However, for remolded samples, temperature and effective stress had less influence on creep index even around the apparent preconsolidation pressure. Moreover, same situation was observed for both remolded and intact samples under higher stress level where dependency of creep index on temperature is not so obvious. The reason of observed difference between remolded and intact samples was attributed by authors to structure arrangement and pore size which is differ considerably between intact and remolded samples and the bonds between solid particles which no longer exists in remolded samples. Also, in this study, the reason of change in creep index due to change in temperature was directed toward the effect of temperature on viscosity of free and bound water and rearrangement of solid particles.

Kaddouri et al. [60] mentioned that creep index increases with increase in temperature and effective stress. Change in soil skeleton and pores areas was believed to be the reason for effect of temperature on creep index in their study. The method proposed by Mersi and Godlewski [66] was also adopted here to study the effect of temperature on creep index in terms of $C_{\alpha} / C_{c}$ and it was observed that $C_{\alpha} /$ $C_{c}$ is increasing with increase in temperature and increase in $C_{\alpha} / C_{c}$ was believed to be mostly dominated by increase in creep index.

\subsection{Cohesion $(C)$ and friction angle $(\phi)$}

Understanding about shearing parameters of soils is crucial in geotechnical design and effect of temperature on these parameters are important in order to satisfy the safety for geotechnical applications dealing with thermal loads and temperature change.

Yavari et al. [39] studied the effect of temperature on friction angles of clay using temperature-controlled direct shear test apparatus and reported that friction angle is 


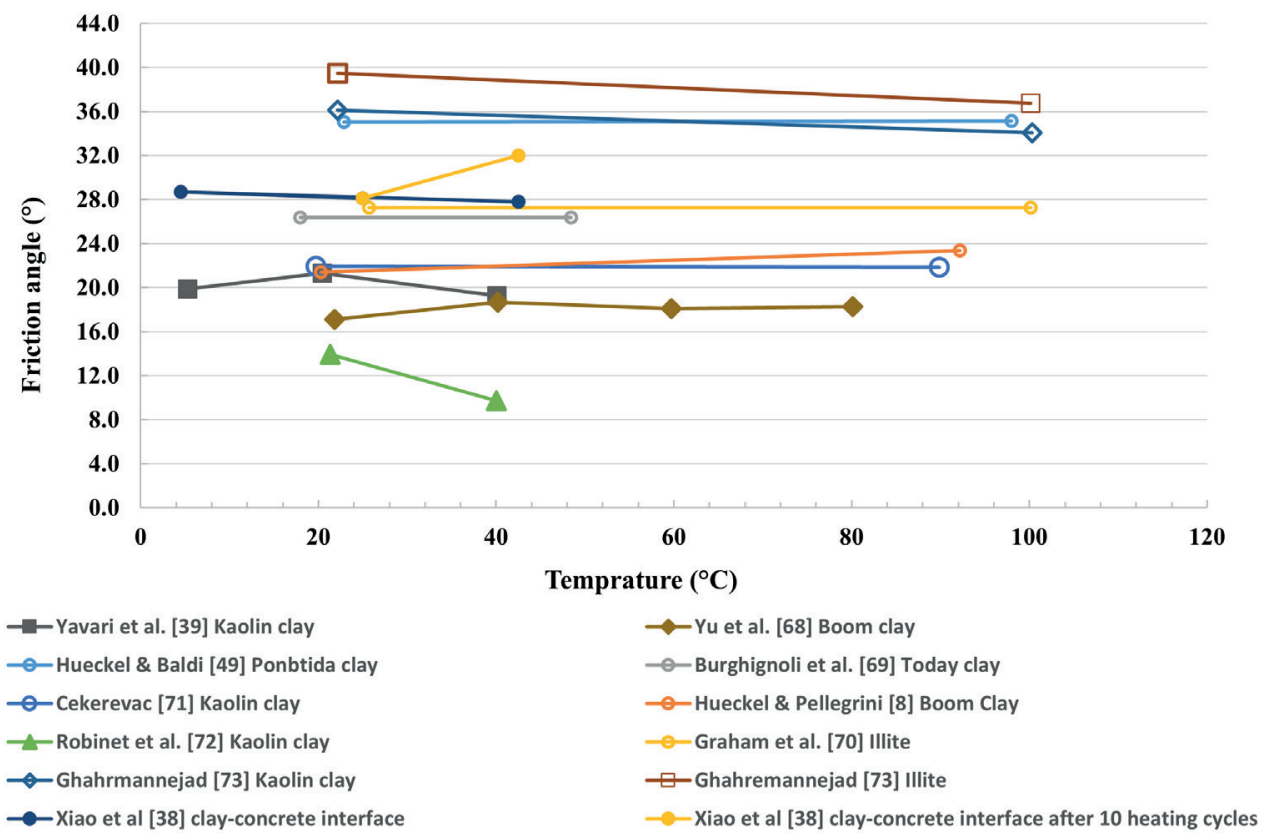

Fig. 7 Effect of temperature on friction angle (after [39])

mostly independent of temperature. Another recent study for temperature effect on shearing parameters is the work of Yu et al. [68] on Boom clay using modified triaxial test. Similar to previous studies, no dependency of friction angle with temperature and clear trend were reported.

Fig. 7 shows the results from literature $([39,67,69-73]$ for different types of fine-grained soil and independency of friction angle on temperature is observed.

Yavari et al. [39] and Yu et al. [68] also studied the effect of temperature change on cohesion of clayey soils. Both decrease and increase are observed in [39] by temperature raise from 5 to $40^{\circ} \mathrm{C}$ in Kaolin clay. Nevertheless, totally at the end of heating, decrease in cohesion was observed. In contrast, Boom clay exhibited rather different behavior and sharp decrease in cohesion by temperature raise from 20 to $80^{\circ} \mathrm{C}$ is reported [68]. It worth to note the difference between testing apparatus and material as well as temperature range for these results.

Xiao et al. [38] conducted direct shear test under cyclic temperature on sandy silty clay and studied the effect of temperature change on interface friction angle and cohesion between soil and concrete with unsaturated condition. Their result show that both normal cooling and heating from ambient temperature caused a slight $\left(<1^{\circ}\right)$ reduction in interface friction angle while cyclic heating and cooling caused almost 3 to $4^{\circ}$ increase in friction angle. In terms of interface cohesion, both normal and cyclic cooling resulted in slight reduction around 0.5 $\mathrm{kPa}$. Normal heating of specimen caused a rather higher decrease in interface cohesion about $5 \mathrm{kPa}$ however, after 10 cycle of heating, interface cohesion increased about 3 $\mathrm{kPa}$ comparing to its initial value. The results of friction angle and cohesion under normal heating are somewhat in agreement with results from other researchers.

Fig. 8 shows the effect of temperature on cohesion with help of results from literature and it can be seen that generally cohesion of fine-grained soils is decreasing with increase in temperature.

After reviewing the results, it can be seen that elevated temperature does not have significant effect on friction angle. Friction angle depends mostly on particle size and shape and temperature does not have much effect on that. However, cohesion depends on plasticity of fine soils and

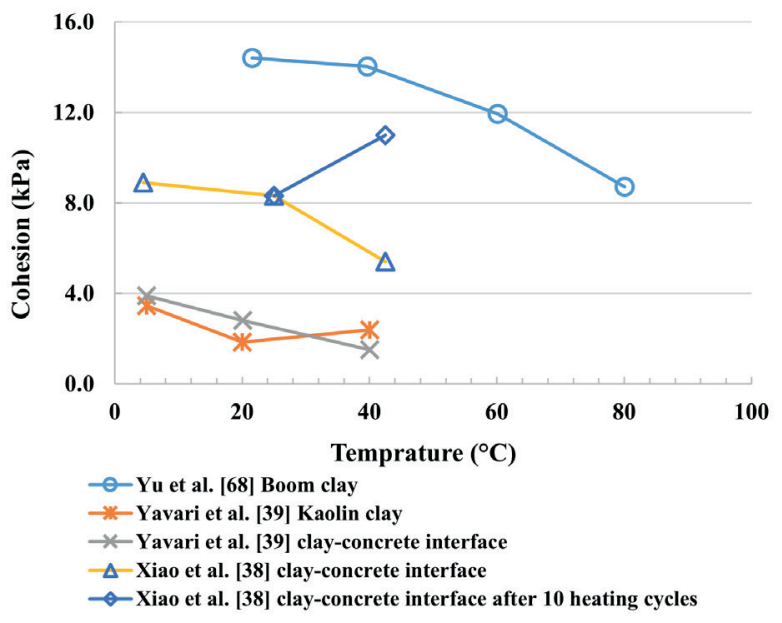

Fig. 8 Effect of temperature on Cohesion 
more importantly on water-clay particle interaction such as double layer thickness and viscous shear resistance between clay particles. As it was discussed previously, elevated temperature is believed to have impact on these properties and causes a reduction in viscous shear resistance between particles which can be seen as a decrease in cohesion. It is also observed that cyclic temperature changes could cause increase in both cohesion and friction angle. This can be due to the fact that after thermal cycles, particles are rearranged and reached a stronger structure which can be interpreted as increase in shear parameters.

\subsection{Strength}

An important aspect of soil properties is change in shear strength toward temperature change, which should be assessed carefully to safely design temperature and thermal related structures. Several studies have been conducted to investigate the effect of temperature on shear strength of soil and it is still an interesting topic among researchers because of its importance.

Laloui and Cekerevac [52, 54] performed drained shearing test using triaxial device under temperature 20 and $90^{\circ} \mathrm{C}$ on Kaolin clay with different OCR value. It is shown that specimens tested under higher temperature experienced higher shear strength for all OCR values. They also studied the effect of temperature on Critical State Line (CSL) and the independency of CSL toward temperature change was concluded.

Abuel-Naga et al. [43] studied the undrained shear strength of soft Bangkok clay, having different values of OCR, under constant heating and cyclic temperature changes using triaxial device. Increase in undrained shear strength with increase in temperature was observed for soft Bangkok clay for all OCR values. The results also showed that cyclic heating caused higher increase in undrained shear strength comparing to constant heating and axial strain in peak deviatoric stress is lower compared to specimen under constant heating.

In contrast with the result of soft Bangkok clay, 30-40 \% reduction in shear strength of Boom clay by raising temperature from 20 to $80^{\circ} \mathrm{C}$ is reported in [68] using triaxial undrained shear test. Failure envelope of Boom clay in $p^{\prime}-q$ plane and slope of critical state line (M) was also studied and, similar to result of Cekerevac and Laloui [52], the independency of $M$ with temperature change was seen. Zhang et al. [16, 17] studied shear strength behavior toward temperature change for highly over consolidated COX (Callovo-Oxfordian) and OPA (Opalinus) clay stones which are host medium for nuclear waste disposal in France and Switzerland, respectively. They reported reduction in shear strength of OPA clay stones under saturated and undrained condition whereas, for COX clay stone, no significant effect of temperature on shear strength was seen.

As it is seen in results, different trend is observed from the experiments for the effect of temperature on strength of soil and the reason for such discrepancy would be the difference in material, mineralogy and tests methods.

\section{Discussion on role of thermally induced structural rearrangement}

Effect of temperature on different mechanical parameters of fine soils were discussed within previous sections by reviewing the results from literature and alternation in some mechanical parameters were reported by researchers including some comments about how temperature affect the mechanical parameters of fine soils. For instance, thermally induced changes in consolidation parameters were related to change in viscosity of water due to temperature change by majority of researchers (Section 2.1). However, different behaviors were observed for consolidation parameters such as $C_{c}, m_{v}$ and $C_{v}$ for different samples and such discrepancy in terms of responses to temperature change was also observed for other mechanical parameters. Within this section of paper, it will be tried to find a possible explanation for the mechanism responsible for thermally induced changes which could help us connect the responses from different mechanical parameters together.

As discussed in Section 2.1.1, viscosity of water will decrease with increase in temperature which will lead to faster movement of water molecules and increase in permeability accordingly. This effect of temperature on physical properties of water has been used by researchers to calculate permeability at different temperature and comparison with experimental data showed good agreement. By this idea, effect of temperature on physical properties of free water in void area is only considered for increase in permeability. However, effect of temperature on viscosity of absorbed double layer (bound water) could be important since any change in double layer thickness can change the size of water channels in soils and affect permeability accordingly. Comparison between early studies in literature about effect of temperature on double layer thickness is well documented in [46]. Some authors proposed a reduction in double layer thickness. For example, Lame's model for effective stress which predicts a decrease in double layer thickness by increasing the temperature. 
Paaswell [2] proposed that increasing temperature will increase movement and kinematic energy of water molecules and as a result, these water molecules can move out of double layer into free water with more ease and therefore thickness of double layer will decrease. Habibagahi [4] also believed that thickness of double layer decreases with increase in temperature. On the other hand, increase in double layer thickness is also proposed by researchers. Yong et al. [74] proposed an increase in double layer thickness by increase in temperature caused by increase in repulsive forces. Morin and Silva [45] proposed that thickness of double layer should increase considering the theoretical formula for calculation of double layer thickness which is related directly to square root of temperature. Mitchel [75], however opposite to proposal in [45], believed that effect of temperature will be neutralized by decrease in dielectric constant considering theoretical formula for double layer thickness. Habibagahi [4] also showed that during a permeability test under different temperature, water molecules in double layer does not change which is opposite of Paaswell's opinion. Very recent work in [47] and Fig. 3 could be a good example to conclude the effect of temperature on water-particle interaction and absorbed double layer where results showed reduction in intrinsic permeability after a heating-cooling cycle. Intrinsic permeability depends only on void ratio of soil and it should not change upon heating and cooling. However more detailed work in [47], in contrast with other early work from literature, proved some structural changes within the soil upon heating which led to reduction in void ratio and intrinsic permeability accordingly.

Therefore, it can be concluded that some microstructural changes or structural rearrangement occurs within the fine soils specially during heating and the mechanism for such structural changes could be related to two different process. Firstly, possible decrease in absorbed double layer thickness and reduction in repulsive forces which can allow particles to rearrange and get closer to each other. Secondly, decrease in viscosity of absorbed double layer which will lead to reduction in viscous shear resistance between particles and easier sliding of particles on each other and structural rearrangement accordingly. With the help of this proposed concept of thermally induced structural rearrangement, responses of other mechanical parameters toward temperature change could be explained.

Another important parameter of fine-grained soil, discussed earlier, is preconsolidation pressure. It is mentioned (Section 2.1.2) that preconsolidation pressure is maximum past pressure experienced by the soil and it is often defined as the yield point. In other words, it means that soil structure is already developed which can resist stresses below preconsolidation pressure, however, stresses higher than preconsolidation pressure will cause structural rearrangement and plastic deformation. Resistance in fine soils is governed by water-particle interaction and viscous shear resistance between particles. Proposed thermally induced structural rearrangement could be interpreted as reduction in preconsolidation pressure since reduction in viscous shear resistance and decrease in double layer thickness can ease structural changes in soil skeleton. As it was proposed by [53], evolution of preconsolidation pressure by temperature change can be predicted by help of parameter $\gamma$ which was related to liquid limit. As it was seen in Fig. 5, higher liquid limit will lead to higher value for $\gamma$ and higher sensitivity of preconsolidation pressure to temperature change. Based on these results, it can be concluded that soil with higher plasticity (higher liquid limit) shows higher sensitivity in terms of reduction in preconsolidation pressure due to increase in temperature. Plasticity of fine soils depends on water- particle interaction and thickness of absorbed double layer. Therefore, effect of temperature on soils with higher plasticity is more dominant and visible which is seen as higher sensitivity of preconsolidation pressure toward temperature changes.

Similar concept can be used to explain response of $C_{v}$ (coefficient of consolidation) to temperature change. Both faster dissipation of excess pore water pressure due to reduction in permeability as well as easier structural rearrangement due to reduction in viscous shear resistance between particles and alternation of water-particle system could accelerate consolidation process which is seen in terms of increase in $C_{v}$ especially with soils with higher plasticity. As it was mentioned earlier, effect of temperature on water-particle system is more visible for soils with higher plasticity which is clearly shown in Fig. 6 in terms of relation between increasing rate of $C_{v}$ and liquid limit.

Increase in volume compressibility $\left(m_{v}\right)$ due to increase in temperature is also reported in literature for some of the samples specially under lower stresses. Thermally induced structural rearrangement of particles can cause the soil to be compressed easier. Compressibility of soil is mostly dominated by the amount of stress for higher stress level and the effect of temperature on rearrangement of particles in not visible however, influence of temperature increase can readily be seen for lower stress levels as it was reported in literature. 
Based on the results from literature, swelling index $\left(C_{s}\right)$ is independent of temperature change however, increase in compression index $\left(C_{c}\right)$ was reported for some samples with rather higher plasticity. When measuring $C_{s}$, soil is in over consolidated state and already developed stronger structure which can resist current stress level therefore, tendency of particles toward structural rearrangement is lower and temperature could not affect this process. On the hand when measuring $C_{c}$, soil is in normal consolidated state and rearrangement of particles started which can be enhanced by increase in temperature specially for soils with higher plasticity and bigger double layer thickness which is under higher influence by temperature change.

Creep index $\left(C_{a}\right)$ is the rate of soil settlement after completion of primary consolidation where all excess pore water pressure is dissipated, and stress is being transferred to solid particles. Therefore, it is directly related to viscous shear resistance between particles and most excepted parameter to change by temperature fluctuation considering the proposed thermally induced structural rearrangement in fine soils. Results from literature showed increase in creep index due to increase in temperature for different types of samples which can be related to decrease in viscous shear resistance between particles as result of decrease in viscosity of bound water.

Continuing development of proposed thermally induced structural rearrangement for other mechanical parameters of soils, decrease in viscosity of absorbed water can lead to reduction in viscous shear resistance between particles and it can be interpreted as a reduction in cohesion which is related to water-particle system. On the other hand, friction angle of soils mostly depends on size and shape of particles which is not influenced by temperature. However, it was observed form literature that thermal cycles can increase both cohesion and friction angle of fine soils. This phenomenon could be due to the fact that soil particles start to rearrange and develop stronger structure and resistance during each cycle which can be seen as an increase in cohesion and friction angle at the end of heating cycles.

Increase in shear strength, due to increase in temperature as well as heating cycles, is also reported in literature which can be related to structural rearrangement of particles and development of stronger bonds and more compact structure. However, reduction in shear strength upon heating is also reported for some samples. In order to understand such discrepancy in results from literature, it worth to highlight the procedure of heating tests prior to shearing tests. Drained heating tests with low heating rate will allow some time for particles to rearrange and development of new structure which can lead to increase in shear strength during subsequent tests at elevated temperature. On the other hand, faster heating tests could lead to development of excess pore pressure as well as decrease in cohesion of fine soils which can lead to reduction in shear strength during subsequent shearing test.

\section{Opportunities, challenges, and future plan}

Aforementioned alternation in mechanical properties of fine soils and proposed thermally induced structural changes can create some advantages and disadvantages at the same time when dealing with geotechnical applications which are exposed to temperature change. Clear understanding about such opportunities and challenges is important and can help engineers for safe design of such geotechnical applications and can also help to form the future path for more detailed research on effect of temperature on soil behavior.

For instance, increase in permeability of fine soils can be utilized to accelerate consolidation process for soft deposits prior to constructions which is commonly done by preloading and using Prefabricated Vertical Drains (PVDs) in some cases. There is an opportunity to decrease the time needed to reach completion of consolidation and thermally induced structural changes could even increase the amount of settlement to reach a more compacted structure under the same amount of preloading. Laboratory and filed-scale tests regarding this application has been successfully done by $[43,76]$ using Thermal Prefabricated Vertical Drains (TPVDs). This could be a promising and environmentally friendly method for soil improvement and stabilization, however, associated costs for providing such equipment and energy to create thermal loads could be a challenge.

Increase in permeability can work in reverse, in some geotechnical application, and create some serious challenges such as design of landfills and underground nuclear waste repository. Generally, some buffer material, such as bentonite, is used for insulation and protection of environment toward leakage of chemical substances or radiation of nuclear wastes. Increase in permeability due to increase in temperature can endanger this insulation capacity of buffer material which should be considered during design of such applications. On the other hand, thermally induced structural changes in soils as well as reduction in shearing parameters due to increase in temperature should be carefully considered specially for design of landfills in slopes, for instance. 
Geothermal energy is attracting high attention as a clean source of energy for space cooling and heating recently around the world. Among different types of geothermal structure, discussed earlier during introduction section, energy pile is a promising method and brings up some opportunities for cost saving by embedding geothermal structure into piles foundation and accessing thermal energy within deeper part of ground as a clean and sustainable source of energy. However, temperature fluctuation inside the pile could be transferred to surrounding soils and affect its mechanical properties which subsequently alter the behavior of an energy pile comparing to conventional pile. Change in cohesion and shearing strength of adjacent soil as well as adhesion between pile and soil can affect the pile capacity and thermally induced structural changes could create potential settlement issue which requires consideration and possible mitigation plan to overcome these mentioned possible obstacles.

Another factor, which is worth to mention for any geotechnical design dealing with temperature change, is increase in creep index reported in literature. Long-term function of such temperature and thermal related application is important and effect of temperature on creep index, as an important long-term factor, requires more detailed assessment.

Trace of thermally induced structural changes as well as responses of water-particle interaction in fine-grained soil can be seen within behavior of different mechanical parameters toward temperature changes. Therefore, it is suggested that focusing on micro and macro structural changes in soils and volume change behavior during temperature change could be a promising path for future research to gain better understanding on behavior of fine soils toward temperature changes. In order to follow this suggestion and as second part of this review process, a detail study on thermally induced volumetric behavior of fine soils is under progress by assessing the results from literature trying to review possible mechanisms responsible for such volumetric changes, possible connection with thermally induced structural changes and connection between volumetric behavior and responses of different mechanical parameters. Meanwhile, a temperature-controlled oedometric test is developed by authors of this paper to study the effect of temperature on volumetric behavior as well as consolidation parameters of fine soils from Budapest, Hungary focusing on creep index and long-term behavior in order to increase and contribute to experimental database of thermally induced changes in fine soils.

\section{Conclusions}

Importance of temperature change and its effect were highlighted by some examples of geotechnical designs dealing with temperature fluctuation.

In following sections, Effect of temperature on mechanical properties of fine-grained soil were investigated and alternation in some parameters was reported in literature. Behavior of different mechanical parameters toward increase in temperature could be summarized as follow:

- Increase in permeability.

- Reduction in preconsolidation pressure.

- Increase in coefficient of consolidation $\left(C_{v}\right)$ and volume compressibility $\left(m_{v}\right)$ for soils with higher plasticity.

- Increase in compression index $\left(C_{c}\right)$ for soils with higher plasticity.

- No visible change in swelling index $\left(C_{s}\right)$.

- Increase in creep index $\left(C_{a}\right)$.

- Decrease in cohesion.

- No visible change in friction angle.

- Both increase and decrease in shear strength

It was tried to find a common factor and a connection which can be responsible for different responses from mechanical parameters toward temperature change observed in literature. It is concluded that the effect of temperature on viscosity of free water, absorbed water, water-particle interaction as well as inter-particle viscous shear resistance are essential which can ease and accelerate structural rearrangement of particles.

In order to finalize this paper, it is stated that trace of particle rearrangement is seen in effect of temperature on majority of mechanical parameters and all of them can be connected to each other with help of proposed thermally induced structural rearrangement concept. Mentioned behavior of mechanical parameters toward temperature change can highlight some positive and negative aspects at the same time which require further assessment and consideration during design of geotechnical applications dealing with temperature change. 


\section{References}

[1] Gary, H. "Progress report on the consolidation of fine-grained soils", In: First International Conference on Soil Mechanics and Foundation Engineering, Harvard, MA, USA, 1936, pp. 138-141.

[2] Paaswell, R. E. "Temperature effects on clay soil consolidation", Journal of the Soil Mechanics and Foundations Division, 93(3), pp. 9-22, 1967.

[3] Campanella, R. G., Mitchell, J. K. "Influence of Temperature Variations on Soil Behavior", Journal of Soil Mechanics \& Foundations Div, 94(SM3), pp. 709-734, 1968. [online] Available at: https://trid.trb.org/view/128027

[4] Habibagahi, K. "Temperature effect and the concept of effective void ratio", Indian Geotechnical Journal, 7(1), pp. 14-34, 1977.

[5] Towhata, I., Kuntiwattanaku, P., Seko, I., Ohishi, K. "Volume Change of Clays Induced by Heating as Observed in Consolidation Tests", Soils and Foundations, 33(4), pp. 170-183, 1993. https://doi.org/10.3208/sandf1972.33.4_170

[6] Houston, S. L., Lin, H.-D. "A thermal consolidation model for pelagic clays", Marine Geotechnology, 7(2), pp. 79-98, 1987. https://doi.org/10.1080/10641198709388209

[7] Plum, R. L., Esrig, M. I. "Some temperature effects on soil compressibility and pore water pressures", Highway Research Board Special Report, 103, pp. 231-242, 1969.

[8] Baldi, G., Hueckel, T., Pellegrini, R. "Thermal volume changes of the mineral-water system in low-porosity clay soils", Canadian Geotechnical Journal, 25(4), pp. 807-825, 1988. https://doi.org/10.1139/t88-089

[9] Sultan, N. "Etude du comportement thermo-mèchanique de 1'argile de Boom: expériences et modélisation" (Study of the thermomechanical behavior of Boom clay: experiments and modeling), $\mathrm{PhD}$ thesis, Ecole Nationale des Ponts et Chaussées, 1997. [online] Available at: https://trid.trb.org/view/959828

[10] Eriksson, L. G. "Temperature effects on consolidation properties of sulphide clays", In: Proceedings of the 12th International Conference on Soil Mechanics and Foundation Engineering, Rio de Janeiro, Brazil, 1989, pp. 2087-2090. [online] Available at: http://www.diva-portal.org/smash/record.jsf?pid=diva2:1006257

[11] Cabalar, A. F., Clayton, C. "Effect of Temperature on Triaxial Behavior of a Sand with Disaccharide", Periodica Polytechnica Civil Engineering, 60(4), pp. 603-609, 2016. https://doi.org/10.3311/PPci.8631

[12] Asszonyi, C., Csatár, A., Fülöp, T. "Elastic, thermal expansion, plastic and rheological processes - theory and experiment", Periodica Polytechnica Civil Engineering, 60(4), pp. 591-601, 2016. https://doi.org/10.3311/PPci.8628

[13] Pápay, Z., Török, Á. "Effect of Thermal and Freeze-thaw Stress on the Mechanical Properties of Porous Limestone", Periodica Polytechnica Civil Engineering, 62(2), pp. 423-428, 2018. https://doi.org/10.3311/PPci.11100

[14] Yu, Q., Zhang, C., Dai, Z., Du, C., Soltanian, M. R., Soltanian, M. "Impact of Tunnel Temperature Variations on Surrounding Rocks in Cold Regions", Periodica Polytechnica Civil Engineering, 63(1), pp. 160-167, 2019.

https://doi.org/10.3311/PPci.13109
[15] Aly, N., Hamed, A., Abd El-Al, A. "The Impact of Hydric Swelling on the Mechanical Behavior of Egyptian Helwan Limestone", Periodica Polytechnica Civil Engineering, 64(2), pp. 589-596, 2020. https://doi.org/10.3311/ppci.15360

[16] Zhang, C.-L. "Thermo-hydro-mechanical behavior of clay rock for deep geological disposal of high-level radioactive waste", Journal of Rock Mechanics and Geotechnical Engineering, 10(5), pp. 9921008, 2018. https://doi.org/10.1016/j.jrmge.2018.03.006

[17] Zhang, C.-L., Conil, N., Armand, G. "Thermal effects on clay rocks for deep disposal of high-level radioactive waste", Journal of Rock Mechanics and Geotechnical Engineering, 9(3), pp. 463-478, 2017. https://doi.org/10.1016/j.jrmge.2016.08.006

[18] Armand, G., Bumbieler, F., Conil, N., de la Vaissière, R., Bosgiraud, J.-M., Vu, M.-N., "Main outcomes from in situ thermo-hydro-mechanical experiments programme to demonstrate feasibility of radioactive high-level waste disposal in the Callovo-Oxfordian claystone", Journal of Rock Mechanics and Geotechnical Engineering, 9(3), pp. 415-427, 2017.

https://doi.org/10.1016/j.jrmge.2017.03.004

[19] Ballarini, E., Graupner, B., Bauer, S. "Thermal-hydraulic-mechanical behavior of bentonite and sand-bentonite materials as seal for a nuclear waste repository: Numerical simulation of column experiments", Applied Clay Science, 135, pp. 289-299, 2017.

https://doi.org/10.1016/j.clay.2016.10.007

[20] Akinwunmi, B., Sun, L., Hirvi, J. T., Kasa, S., Pakkanen, T. A. "Influence of temperature on the swelling pressure of bentonite clay", Chemical Physics, 516, pp. 177-181, 2019. https://doi.org/10.1016/j.chemphys.2018.09.009

[21] Ghazi Zadeh, S., Bareither, C. A. "Temperature-Dependent Shear Behavior of Geosynthetic Clay Liners", In: Geotechnical Frontiers 2017: Geotechnical Materials, Modeling, and Testing, Orlando, FL, USA, 2017, pp. 288-298.

[22] Hanson, J. L., Yesiller, N., Allen, E. P. "Temperature Effects on the Swelling and Bentonite Extrusion Characteristics of GCLs", In: Geotechnical Frontiers 2017: Geotechnical Materials, Modeling, and Testing, Orlando, FL, USA, 2017, pp. 209-219. https://doi.org/10.1061/9780784480472.022

[23] McWatters, R. S., Rowe, R. K., Jones, D. D. "Coextruded geomembranes in barrier systems in extreme environments - From high temperature laboratory tests to Antarctic field sites", In: Geosynthetics 2015, Portland, OR, USA, 2015, pp. 1245-1253.

[24] Thiel, R., Smith, M. E. "State of the practice review of heap leach pad design issues", Geotextiles and Geomembranes, 22(6), pp. 555568, 2004.

https://doi.org/10.1016/j.geotexmem.2004.05.002

[25] Steemson, M. L., Smith, M. E. "The development of nickel laterite heap leach projects", presented at the Australasian Language Technology Association Workshop, ALTA 2009, Sydney, Australia, Dec, 3-4, 2009.

[26] Yeşiller, N., Hanson, J. L., Yee, E. H. "Waste heat generation: A comprehensive review", Waste Management, 42, pp. 166-179, 2015. https://doi.org/10.1016/J.WASMAN.2015.04.004 
[27] Stark, T. D., Martin, J. W., Gerbasi, G. T., Thalhamer, T., Gortner, R. E. "Aluminum Waste Reaction Indicators in a Municipal Solid Waste Landfill", Journal of Geotechnical and Geoenvironmental Engineering, 138(3), 2012. https://doi.org/10.1061/(ASCE)GT.1943-5606.0000581

[28] Aresti, L., Christodoulides, P., Florides, G. "A review of the design aspects of ground heat exchangers", Renewable and Sustainable Energy Reviews, 92, pp. 757-773, 2018. https://doi.org/10.1016/j.rser.2018.04.053

[29] Xing, L., Li, L., Nan, C., Hu, P. "The Effects of Different Land Covers on Foundation Heat Exchangers Design in Chinese Rural Areas", Procedia Engineering, 205, pp. 2449-2456, 2017. https://doi.org/10.1016/j.proeng.2017.09.972

[30] Lines, S., Williams, D. J., Galindo-Torres, S. A. "Determination of Thermal Conductivity of Soil Using Standard Cone Penetration Test", Energy Procedia, 118, pp. 172-178, 2017. https://doi.org/10.1016/j.egypro.2017.07.036

[31] Wang, D., Lu, L., Cui, P. "Simulation of thermo-mechanical performance of pile geothermal heat exchanger (PGHE) considering temperature-depend interface behavior", Applied Thermal Engineering, 139, pp. 356-366, 2018. https://doi.org/10.1016/j.applthermaleng.2018.02.020

[32] Ji, Y., Qian, H., Zheng, X. "Development and validation of a three-dimensional numerical model for predicting the ground temperature distribution", Energy and Buildings, 140, pp. 261-267, 2017. https://doi.org/10.1016/j.enbuild.2017.01.079

[33] Bryś, K., Bryś, T., Sayegh, M. A., Ojrzyńska, H. "Subsurface shallow depth soil layers thermal potential for ground heat pumps in Poland", Energy and Buildings, 165, pp. 64-75, 2018. https://doi.org/10.1016/j.enbuild.2018.01.015

[34] Akhmetov, B., Georgiev, A., Popov, R., Turtayeva, Z., Kaltayev, A., Ding, Y. "A novel hybrid approach for in-situ determining the thermal properties of subsurface layers around borehole heat exchanger", International Journal of Heat and Mass Transfer, 126(A), pp. 11381149, 2018.

https://doi.org/10.1016/j.ijheatmasstransfer.2018.05.107

[35] Liu, W., Xu, M. "2D Axisymmetric Model Research of Helical Heat Exchanger inside Pile Foundations", Procedia Engineering, 205, pp. 3503-3510, 2017.

https://doi.org/10.1016/j.proeng.2017.09.914

[36] Morino, K., Oka, T. "Study on heat exchanged in soil by circulating water in a steel pile", Energy and Buildings, 21(1), pp. 65-78, 1994. https://doi.org/10.1016/0378-7788(94)90017-5

[37] Laloui, L., Nuth, M., Vulliet, L. "Experimental and numerical investigations of the behaviour of a heat exchanger pile", International Journal for Numerical and Analytical Methods in Geomechanics, 30(8), pp. 763-781, 2006.

https://doi.org/10.1002/nag.499

[38] Xiao, S., Suleiman, M. T., Elzeiny, R., Xie, H. "Soil-Concrete Interface Properties Subjected to Temperature Change $\mathrm{s}$ and Cycles Using Direct Shear Tests", In: Geotechnical Frontiers 2017: Geotechnical Materials, Modeling, and Testing, Orlando, FL, USA, 2017, pp. 175-183.

https://doi.org/10.1061/9780784480472.018
[39] Yavari, N., Tang, A. M., Pereira, J.-M., Hassen, G. "Effect of temperature on the shear strength of soils and the soil-structure interface", Canadian Geotechnical Journal, 53(7), pp. 1186-1194, 2016. https://doi.org/10.1139/cgj-2015-0355

[40] Xiao, S., Suleiman, M. T., Elzeiny, R., Naito, C., Neti, S., Al-Khawaja, M. "Effect of Temperature and Radial Displacement Cycles on SoilConcrete Interface Properties Using Modified Thermal Borehole Shear Test", Journal of Geotechnical and Geoenvironmental Engineering, 144(7), Article No. 04018036, 2018. https://doi.org/10.1061/(ASCE)GT.1943-5606.0001892

[41] Faizal, M., Bouazza, A., Haberfield, C., McCartney, J. S. "Axial and Radial Thermal Responses of a Field-Scale Energy Pile under Monotonic and Cyclic Temperature Changes", Journal of Geotechnical and Geoenvironmental Engineering, 144(10), 2018. https://doi.org/10.1061/(ASCE)GT.1943-5606.0001952

[42] Hillel, D. "Fundamentals of soil physics", Academic Press, New York, NY, USA, 1980.

[43] Abuel-Naga, H. M., Bergado, D. T., Chaiprakaikeow, S. "Innovative thermal technique for enhancing the performance of prefabricated vertical drain during the preloading process", Geotextiles and Geomembranes, 24(6), pp. 359-370, 2006. https://doi.org/10.1016/j.geotexmem.2006.04.003

[44] Abuel-Naga, H. M., Bergado, D. T., Soralump, S., Rujivipat, P. "Thermal consolidation of soft Bangkok clay", Lowland Technology International, 7(1), pp. 13-21, 2005.

[45] Morin, R., Silva, A. J. "The effects of high pressure and high temperature on some physical properties of ocean sediments", Journal of Geophysical Research: Solid Earth, 89(B1), pp. 511-526, 1984. https://doi.org/10.1029/JB089iB01p00511

[46] Delage, P., Sultan, N., Cui, Y.-J., Pascal, A. B. "On the thermal consolidation of Boom clay", Canadian Geotechnical Journal, 37(2), pp. 343-354, 2000.

https://doi.org/10.1139/t99-105

[47] Chen, W. Z., Ma, Y. S., Yu, H. D., Li, F. F., Li, X. L., Sillen, X. "Effects of temperature and thermally-induced microstructure change on hydraulic conductivity of Boom Clay", Journal of Rock Mechanics and Geotechnical Engineering, 9(3), pp. 383-395, 2017. https://doi.org/10.1016/j.jrmge.2017.03.006

[48] Sultan, N., Delage, P., Cui, Y. J. "Temperature effects on the volume change behaviour of Boom clay", Engineering Geology, 64, pp. 135-145, 2002. https://doi.org/10.1016/S0013-7952(01)00143-0

[49] Hueckel, T., Baldi, G. "Thermoplasticity of Saturated Clays: Experimental Constitutive Study", Journal of Geotechnical Engineering, 116(12), pp. 1778-1796, 1990. https://doi.org/10.1061/(ASCE)0733-9410(1990)116:12(1778)

[50] Picard, J.-M. "Ecrouissage thermique des argiles saturées: application au stockage des déchets radioactifs" (Thermal hardening of saturated clays: application to the disposal of radioactive waste), $\mathrm{PhD}$ Thesis, Ecole Nationale des Ponts et Chaussées, 1994.

[51] Baldi, G., Hueckel, T., Peano, A., Pellegrini, R. "Developments in modelling of thermo-hydro-geomechanical behaviour of boom clay and clay-based buffer materials", Commission of the European Communities, Brussels, Belgium, Rep. EUR 13365, 1991. 
[52] Cekerevac, C., Laloui, L. "Experimental study of thermal effects on the mechanical behaviour of a clay", International Journal for Numerical and Analytical Methods in Geomechanics, 28(3), pp. 209-228, 2004. https://doi.org/10.1002/nag.332

[53] Cekerevac, C., Laloui, L., Vulliet, L. "Dependency law for thermal evolution of preconsolidation pressure", In: 8th. International Symposium on N Numerical Models in Geomechanics - NUMOG VIII, Rome, Italy, 2002, pp. 687-692. https://doi.org/10.1201/9781439833797-c102

[54] Laloui, L., Cekerevac, C. "Numerical simulation of the non-isothermal mechanical behaviour of soils", Computers and Geotechnics, 35(5), pp. 729-745, 2008. https://doi.org/10.1016/j.compgeo.2007.11.007

[55] Moritz, L. "Geotechnical Properties of Clay at Elevated Temperatures", Swedish Geotechnical Institute, Linköping, Sweden, Rep. 47, 1995.

[56] Tsutsumi, A., Tanaka, H. "Combined effects of strain rate and temperature on consolidation behavior of clayey soils", Soils and Foundations, 52(2), pp. 207-215, 2012. https://doi.org/10.1016/j.sandf.2012.02.001

[57] Jarad, N., Cuisinier, O., Masrouri, F. "Effect of temperature and strain rate on the consolidation behaviour of compacted clayey soils", European Journal of Environmental and Civil Engineering, 23(7), pp. 789-806, 2017.

https://doi.org/10.1080/19648189.2017.1311806

[58] Xiong, Y., Yang, Q., Sang, Q., Zhu, Y., Zhang, S., Zheng, R. "A unified thermal-hardening and thermal-softening constitutive model of soils", Applied Mathematical Modelling, 74, pp. 73-84, 2019. https://doi.org/10.1016/j.apm.2019.04.034

[59] Uchaipichat, A. "Experimental investigation and constitutive modelling of thermo-hydro-mechanical coupling in unsaturated soils", PhD Thesis, University of New South Wales, 2005.

[60] Kaddouri, Z., Cuisinier, O., Masrouri, F. "Influence of effective stress and temperature on the creep behavior of a saturated compacted clayey soil", Geomechanics for Energy and the Environment, 17, pp. 106-114, 2019. https://doi.org/10.1016/j.gete.2018.09.002

[61] Hueckel, T., Borsetto, M. "Thermoplasticity of Saturated Soils and Shales: Constitutive Equations", Journal of Geotechnical Engineering, 116(12), pp. 1765-1777, 1990 https://doi.org/10.1061/(ASCE)0733-9410(1990)116:12(1765)

[62] Bag, R., Rabbani, A. "Effect of temperature on swelling pressure and compressibility characteristics of soil", Applied Clay Science, 136, pp. 1-7, 2017. https://doi.org/10.1016/j.clay.2016.10.043

[63] Takai, A., Akama, T., Inui, T., Katsumi, T., Ogawa, A. "Laboratory Tests on Thermal Improvement of Soft Clay Under Elevated Temperatures", In: Ferrari, A., Laloui, L. (eds.) Energy Geotechnics, Springer, Cham, Switzerland, 2018, pp. 75-82. https://doi.org/10.1007/978-3-319-99670-7_10

[64] Mon, E. E., Hamamoto, S., Kawamoto, K., Komatsu, T., Møldrup, P. "Temperature Effects on Geotechnical Properties of Kaolin Clay: Simultaneous Measurements of Consolidation Characteristics, Shear Stiffness and Permeability Using a Modified Oedometer", GSTF Journal of Geological Sciences (JGS), 1(1), 2013.

https://doi.org/10.5176/2335-6774_1.1.1
[65] Di Donna, A., Laloui, L. "Response of soil subjected to thermal cyclic loading: Experimental and constitutive study", Engineering Geology, 190, pp. 65-76, 2015.

https://doi.org/10.1016/j.enggeo.2015.03.003

[66] Mesri, G., Godlewski, P. M. "Time and Stress-Compressibility Interrelationship", Journal of the Geotechnical Engineering Division, 103(5), pp. 417-430, 1997.

[67] Li, Y., Dijkstra, J., Karstunen, M. "Thermomechanical Creep in Sensitive Clays", Journal of Geotechnical and Geoenvironmental Engineering, 144(11), 2018. https://doi.org/10.1061/(ASCE)GT.1943-5606.0001965

[68] Yu, H., Chen, W., Gong, Z., Ma, Y., Chen, G., Li, X. "Influence of temperature on the hydro-mechanical behavior of Boom Clay", International Journal of Rock Mechanics and Mining Sciences, 108, pp. 189-197, 2018. https://doi.org/10.1016/j.ijrmms.2018.04.023

[69] Burghignoli, A., Desideri, A., Miliziano, S. "A laboratory study on the thermomechanical behaviour of clayey soils", Canadian Geotechnical Journal, 37(4), pp. 764-780, 2000. https://doi.org/10.1139/t00-010

[70] Graham, J., Tanaka, N., Crilly, T., Alfaro, M. "Modified Cam-Clay modelling of temperature effects in clays", Canadian Geotechnical Journal, 38(3), pp. 608-621, 2001. https://doi.org/10.1139/t00-125

[71] Cekerevac, C. "Thermal effects on the mechanical behaviour of saturated clays", PhD Thesis, École Polytechnique Fédérale de Lausanne, 2003.

[72] Robinet, J.-C., Pasquiou, A., Jullien, A., Belanteur, N., Plas, F. "Expériences de laboratoire sur le comportement thermo-hydro-mécanique de matériaux argileux remaniés gonflants et non gonflants" (Laboratory experiments on the thermo-hydro-mechanical behaviours of swelling and unswelling clayey rocks), Revue Française de Géotechnique, (81), pp. 53-80, 1997. https://doi.org/10.1051/geotech/1997081053

[73] Ghahremannejad, B. "Thermo-mechanical behaviour of two reconstituted clays", PhD Thesis, École Polytechnique Fédérale de Lausanne, 2003.

[74] Yong, R. "Swelling Pressures of Sodium Montmorillonite at Depressed Temperatures", Clays and Clay Minerals, 11, pp. 268281, 1962.

https://doi.org/10.1346/ccmn.1962.0110126

[75] Mitchell, J. K. "Fundamentals of Soil Behavior", Wiley, New York, NY, USA, 1993.

[76] Pothiraksanon, C., Bergado, D. T., Abuel-Naga, H. M. "Full-Scale Embankment Consolidation Test using Prefabricated Vertical Thermal Drains", Soils and Foundations, 50(5), pp. 599-608, 2010. https://doi.org/10.3208/sandf.50.599 